\title{
The effect of increasing postruminal methionine supply on lactational responses in dairy cows
}

\author{
PM Pisulewski, H Rulquin, R Vérité \\ INRA, Station de Recherches sur la Vache Laitière, 35590 Saint-Gilles, France
}

Methionine has been suggested (eg, Rulquin, 1987), as a limiting amino acid for milk protein synthesis. The objective of this study was to determine dose-response relationships between graded duodenal methionine infusion levels and milk protein yield and content, in high-producing dairy cows.

Five Holstein cows, fitted with duodenal cannulae were offered twice daily a complete diet containing: maize silage $64 \%$; rumen-protected soybean meal $8.83 \%$; soybean meal $6.3 \%$; cereals $14 \%$; urea $0.56 \%$; molasses $0.4 \%$; minerals $0.87 \%$; and alfalfa hay $5 \%$, on a dry matter basis. The animals were assigned to $5 \times 5$ latin square design in which the treatments were continuous (14 d) infusions of DL-methionine: $0,6,12,18$ and
$24 \mathrm{~g} / \mathrm{d}$ in a total volume of $5000 \mathrm{ml}$ water; each with a constant infusion of L-lysine $(10 \mathrm{~g} / \mathrm{d})$.

The treatments did not affect dry matter intake, milk yield, fat yield or content. In contrast, milk protein yield and content and casein percentage were regularly $(P<0.05)$ increased, with increasing amounts of methionine (table I). It is concluded that postruminal methionine supplementation may be seen as an efficient method of increasing milk protein yield and content in cows fed maize silage-soybean meal diets.

Rhône Poulenc Nutrition Animale is gratefully acknowledged for financial support.

Rulquin H (1987) Reprod Nutr Develop 27, 299. 300

Table l. The effects of duodenal infusions of methionine on feed intake, milk yieid and its composition.

\begin{tabular}{|c|c|c|c|c|c|c|}
\hline \multirow[t]{2}{*}{ Parameter } & \multicolumn{6}{|c|}{ Infusion level $(g / d)$} \\
\hline & 0 & 6 & 12 & 18 & 24 & $S E$ \\
\hline DMI $(\mathrm{kg} / \mathrm{d})$ & 23.0 & 22.2 & 22.6 & 23.1 & 22.9 & 0.78 \\
\hline Milk yield $(\mathrm{kg} / \mathrm{d})$ & 37.5 & 37.9 & 36.3 & 36.6 & 37.9 & 1.53 \\
\hline Protein yield $(\mathrm{g} / \mathrm{d})$ & $1014^{b}$ & 1039 ab & $1054 a b$ & $1071 a b$ & $1099^{a}$ & 43 \\
\hline Protein content $(\mathrm{g} / \mathrm{kg})$ & $27.2^{c}$ & $27.6 \mathrm{bc}$ & 28.6 ba & 29.4 a & 29.7 a & 0.88 \\
\hline Casein/protein (\%) & $81.0^{b}$ & $81.5^{a b}$ & $81.7^{\mathrm{ab}}$ & $82.3 \mathrm{ab}$ & $82.5^{a}$ & 0.91 \\
\hline Fat yield $(\mathrm{g} / \mathrm{d})$ & 1297 & 1320 & 1247 & 1253 & 1287 & 58 \\
\hline Fat content $(\mathrm{g} / \mathrm{kg})$ & 34.4 & 34.5 & 33.8 & 34.3 & 34.8 & 1.69 \\
\hline
\end{tabular}

a, b, c Treatment means of rows differ significantly $(P<0.05)$. 